AGH DRILLING, OIL, GAS • Vol. 35 • No. 1 • 2018

http://dx.doi.org/10.7494/drill.2018.35.1.335

Jan Macuda*, Ewa Styrkowiec**, Witold Rajpold****

\title{
IMPACT OF WELLS RECONSTRUCTION ON THEIR OPERATIONAL PARAMETERS*****
}

\section{INTRODUCTION}

Due to their stable chemical composition and relatively high yield, the underground water from deep water-bearing horizons is often used for municipal and industrial purposes. Its main users are usually water utilities, for whom the principal goal is to supply good quality water to the population. However, using deep water-bearing horizons entails high construction costs of the intake wells. The costs mainly include the drilling, but expensive casing pipes and modern well filters with good hydraulic parameters also contribute significantly to the overall costs. On the other hand, "ageing" processes during the well operation weaken its structure and cause clogging of the filter and the aquifer near the filter. Noticeable effects of these processes include a reduction of hydraulic efficiency and, in many cases, increased well sanding-up. This symptom is a consequence of both higher water inflow speed to the well as a result of clogging processes and the well failure caused by corrosion of the casing pipes and/or the filter. A decision is most often made in such cases to reconstruct a well in order to restore its efficiency. The key stage that guarantees the correct performance of the reconstruction works is reliable well hole diagnostics that should provide full information on its technical condition.

The paper analyses the impact of reconstruction of Lower Cretaceous water wells on maintaining their yield in the light of long-term use. The wells are operated for water supply to the cities of Skierniewice and Łódź.

* AGH University of Science and Technology, Faculty of Drilling, Oil and Gas, Krakow, Poland

** Zakład Wodociągów i Kanalizacji Sp. z o.o., Łódź, Poland

*** GWE POL-BUD Sp. z o.o., Łódź, Poland

**** This study was supported by AGH University of Science and Technology statutory research no. 11.11.190.555 


\section{RECONSTRUCTION OF INTAKE WELLS}

Reconstruction of intake wells involves performing a scope of works in the well hole to restore its adequate technical condition for allowing further water extraction. Such works usually include the repair or replacement of the well's structural components damaged during the construction stage or use [3,4]. Sometimes the reconstruction is also understood as the well deepening in order to extract water from deeper aquifers $[2,5]$.

In wells operated by water utilities, reconstructions are usually related to repair or replacement of casing pipes and filters and to the deepening or shallowing of wells. Reconstruction works should always be preceded by a full well diagnostics, allowing the choice of the optimum and economically justified reconstruction method. The well recommissioning, following the reconstruction works, involves a new determination of the well operational parameters and the actual technical and hydraulic efficiency of the water equipment. A modification of the well construction by shortening the active filter part and reduction of its diameter requires a verification of the determined operational resources for the well, particularly in the light of its long-term use [3].

\section{MODERN DESIGN OF WELL FILTERS}

The Johnson continuous slot screen (Fig. 1) is now the best design available on the market in terms of hydraulics and strength and it has a relatively favourable price-to-quality ratio. Its additional features include high resistance to the well ageing processes, related mainly to chemical and physical clogging. A special filter design has eliminated some drawbacks present in traditional well screens, and use of materials highly resistant to corrosion has resulted in a significantly longer well life.

a)

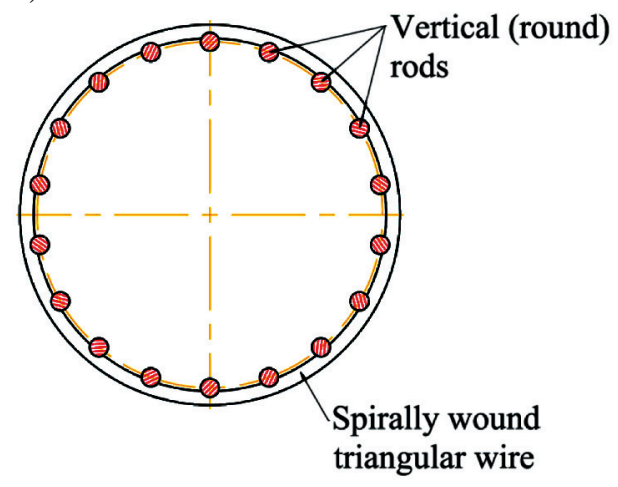

b)

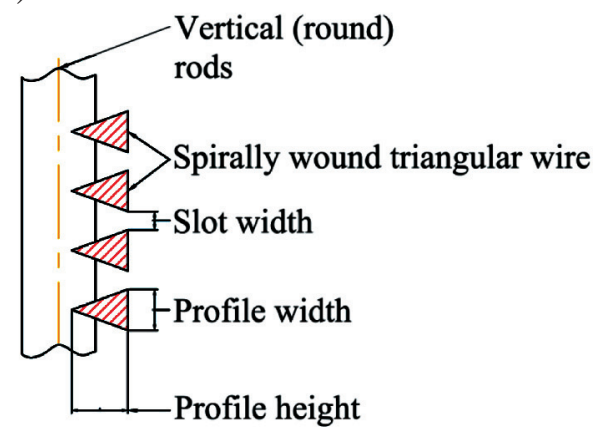

Fig. 1. Johnson continuous slot screen [1]: a) cross section; b) vertical section 
Design-wise, the screen comprises round vertical rods which provide its tensile strength, ensure a circular shape and are used to fasten selected connectors. A triangular wire is wound on the vertical rods on the outside and is joined with them by welding (Fig. 1b). The wound wire provides the screen resistance to both internal and external pressure. The distance between the edges of the wound wire (slot) is the same on the entire screen surface, which directly translates into a several fold increase of the screen active surface. Application of high-grade stainless steel and triangular wound wire allows for using the screen for extraction of water from a depth in excess of $3000 \mathrm{~m}$. Table 1 presents the technical parameters of Johnson screens used for the reconstruction of the Lower Cretaceous water wells in Łódź and Skierniewice.

Table 1

Technical parameters of Johnson screens used for the reconstruction of water wells in Łódź and Skierniewice

\begin{tabular}{|l|c|c|}
\hline \multicolumn{1}{|c|}{ Parameter } & 1z well - Lódź & 1a well - Skierniewice \\
\hline Nominal diameter [mm] & DN 250 & DN 150 \\
\hline Outside diameter [mm] & 270.00 & 163.00 \\
\hline Inside diameter [mm] & 248.00 & 150.00 \\
\hline Diameter on joint [mm] & 300.00 & 190.00 \\
\hline Slot width [mm] & 1.80 & 0.75 \\
\hline Active area [\%] & 30.00 & 24.59 \\
\hline Unit yield* [m $3 / \mathrm{h}$ from $1 \mathrm{~m}]$ & 27.32 & 13.42 \\
\hline Wound wire type & W420N & W230N \\
\hline $\begin{array}{l}\text { Vertical rods [dia } \times \text { pcs] } \\
\text { on circumference [mm } \times \text { pcs] }\end{array}$ & $4 \times 50$ & $3 \times 30$ \\
\hline Resistance to crushing pressure [bar] & 45.44 & 36.88 \\
\hline
\end{tabular}

* at assumed inflow sped of $3 \mathrm{~cm} / \mathrm{s}$

\section{CHARACTERISTICS OF THE RECONSTRUCTED WELLS}

The cities of Łódź and Skierniewice are about $50 \mathrm{~km}$ apart, but the geological structure of both regions is similar due to the situation on opposite wings of a basin belonging to the Szczecin-Lodz-Miechow Synclinorium and built of Cretaceous formations (Fig. 2). Deep water intake wells, 1a in Skierniewice and 1z in Lódź, extract water from the Lower Cretaceous level within weakly consolidated sandstones interbedded with claystones and 
mudstones. Within the drilled Lower Cretaceous formations location is a relatively thick ( $\sim 8.5-22.0 \mathrm{~m})$ layer of mudstones that forms a natural barrier for water flow between the sandstone layers. This impermeable package is most likely widespread, which results in the separation of the sandstone formations.

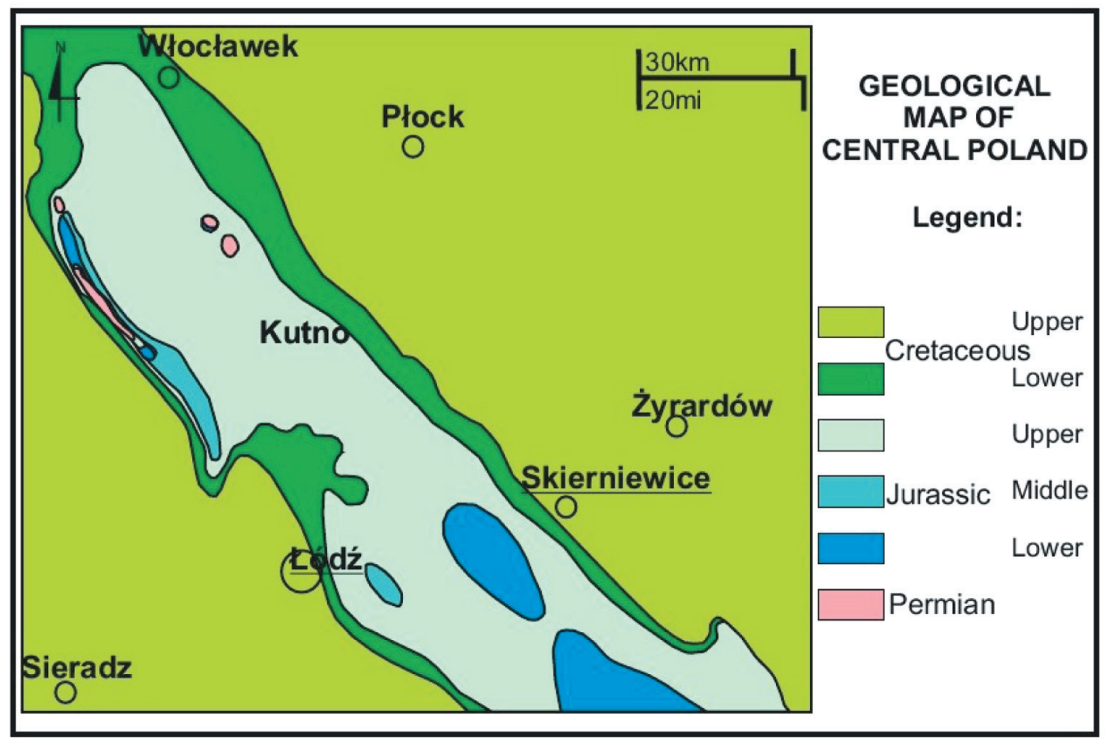

Fig. 2. Fragment of a simplified geological map of Łódź and Skierniewice area, Poland [7]

The said Lower Cretaceous water wells $1 \mathrm{a}$ and $1 \mathrm{z}$ are similar in design and were drilled in 1990. The underground water was extracted using the screens of perforated carbon steel tubes - available on the market at that time - on the outside wrapped with galvanised sheet with bridge slot perforation. A combination of two structural components of varying electric potential in the same screen resulted in a quick electrochemical corrosion, and consequently in a reduced screen strength and an accelerated deterioration of the technical condition of the wells. The operational reports of the said wells indicate that in both cases the sanding-up occurred already after about 4 years of operation, and the well diagnostics showed a significant backfill (about 60-70 m).

The need to keep the wells and their operational resources in operation was the reason for the reconstruction. The reconstruction works on both wells involved a replacement of the damaged screens with new ones of definitely better mechanical and hydraulic parameters. During the works, a decision was made to install the screens on, and to extract water from, only the top part of the aquifer. The bottom part of the well hole was eliminated by making a cement plug on a natural backfill in the interval of impermeable mudstone layers. The need to maintain the operational yield in both 
intakes at the level of determined resources, and the simultaneous shortening of the screen active part, encouraged the Employer to use a Jonson stainless steel, continuous slot screen which has a very large active area. Table 2 presents the constructional parameters of both wells before and after reconstruction.

Table 2

Constructional parameters of the Lower Cretaceous water wells in Skierniewice (1a) and Łódź (1z) [7]

\begin{tabular}{|c|c|c|c|c|c|c|}
\hline \multirow[b]{2}{*}{ 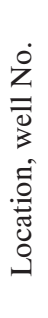 } & \multicolumn{3}{|c|}{ Before reconstruction } & \multicolumn{3}{|c|}{ After reconstruction } \\
\hline & $\begin{array}{c}\begin{array}{c}\text { Original } \\
\text { well depth } \\
\text { [m BGL] }\end{array} \\
\text { Aquifer } \\
\text { roof } \\
{[\mathrm{m} \mathrm{BGL}]}\end{array}$ & $\begin{array}{c}\begin{array}{c}\text { Screened } \\
\text { section } \\
\text { [m BGL] }\end{array} \\
\text { Screen } \\
\text { length } \\
\text { [m] }\end{array}$ & $\begin{array}{l}\text { Screen } \\
\text { type }\end{array}$ & $\begin{array}{l}\text { Well depth } \\
\text { after recon- } \\
\text { struction } \\
\text { [m BGL] }\end{array}$ & $\begin{array}{c}\begin{array}{c}\text { Screened } \\
\text { section } \\
\text { [m BGL] }\end{array} \\
\text { Screen } \\
\text { length } \\
\text { [m] }\end{array}$ & $\begin{array}{l}\text { Screen } \\
\text { type }\end{array}$ \\
\hline 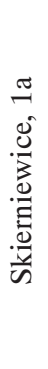 & $\begin{array}{l}583.0 \\
451.0\end{array}$ & $\begin{array}{c}453.6- \\
559.6 \\
80.64\end{array}$ & $\begin{array}{c}\text { Perforated } \\
\text { steel tube } \\
\varnothing 95 / 8 ", \\
\text { wrapped } \\
\text { with } 1 \mathrm{~mm} \\
\text { galvanised } \\
\text { sheet with } \\
\text { bridge } \\
\text { slot perfo- } \\
\text { ration }\end{array}$ & 513.0 & $\begin{array}{c}454.0- \\
494.0 \\
40.0\end{array}$ & $\begin{array}{c}\text { Johnson } \\
\text { DN 150, } \\
\text { stainless } \\
\text { steel }\end{array}$ \\
\hline 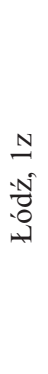 & $\frac{618.5}{461.5}$ & $\begin{array}{c}461.0- \\
597.3 \\
136.3\end{array}$ & $\begin{array}{c}\text { Perforated } \\
\text { steel tube } \\
\varnothing 113 / 4 ", \\
\text { wrapped } \\
\text { with } 2 \mathrm{~mm} \\
\text { galvanised } \\
\text { sheet with } \\
\text { bridge } \\
\text { slot perfo- } \\
\text { ration }\end{array}$ & 491.0 & $\begin{array}{c}463.0- \\
488.0 \\
25.0\end{array}$ & $\begin{array}{c}\text { Johnson } \\
\text { DN 250, } \\
\text { stainless } \\
\text { steel }\end{array}$ \\
\hline
\end{tabular}

\section{WELL OPERATION AFTER RECONSTRUCTION}

After the reconstruction, the operational yield of the 1a well was kept at the level specified during its construction, and the yield of the $1 \mathrm{z}$ well was slightly reduced. Such an approach resulted in a significantly increased depression, e.g. more than double in the 1a well. Hence, the keeping of the operational yield resulted in an increased speed 
of water flowing to the well in the aquifer part that had the screens installed, and consequently in an increased hydraulic resistance and reduced hydraulic efficiency of both wells. In addition, the test pumping after reconstruction showed a reduced filtration ratio in the 1a well for the top part of the aquifer, indicating a change of the aquifer permeability in the zone close to the screen as a result of 20 years of well operation [6]. Generally, it can be said that such a long operation of the well has decreased the aquifer filtration ratio in the zone affected by the water intakes (Tab. 3).

Table 3

Typical operational parameters of the Lower Cretaceous aquifer water wells over about 20 years of operation

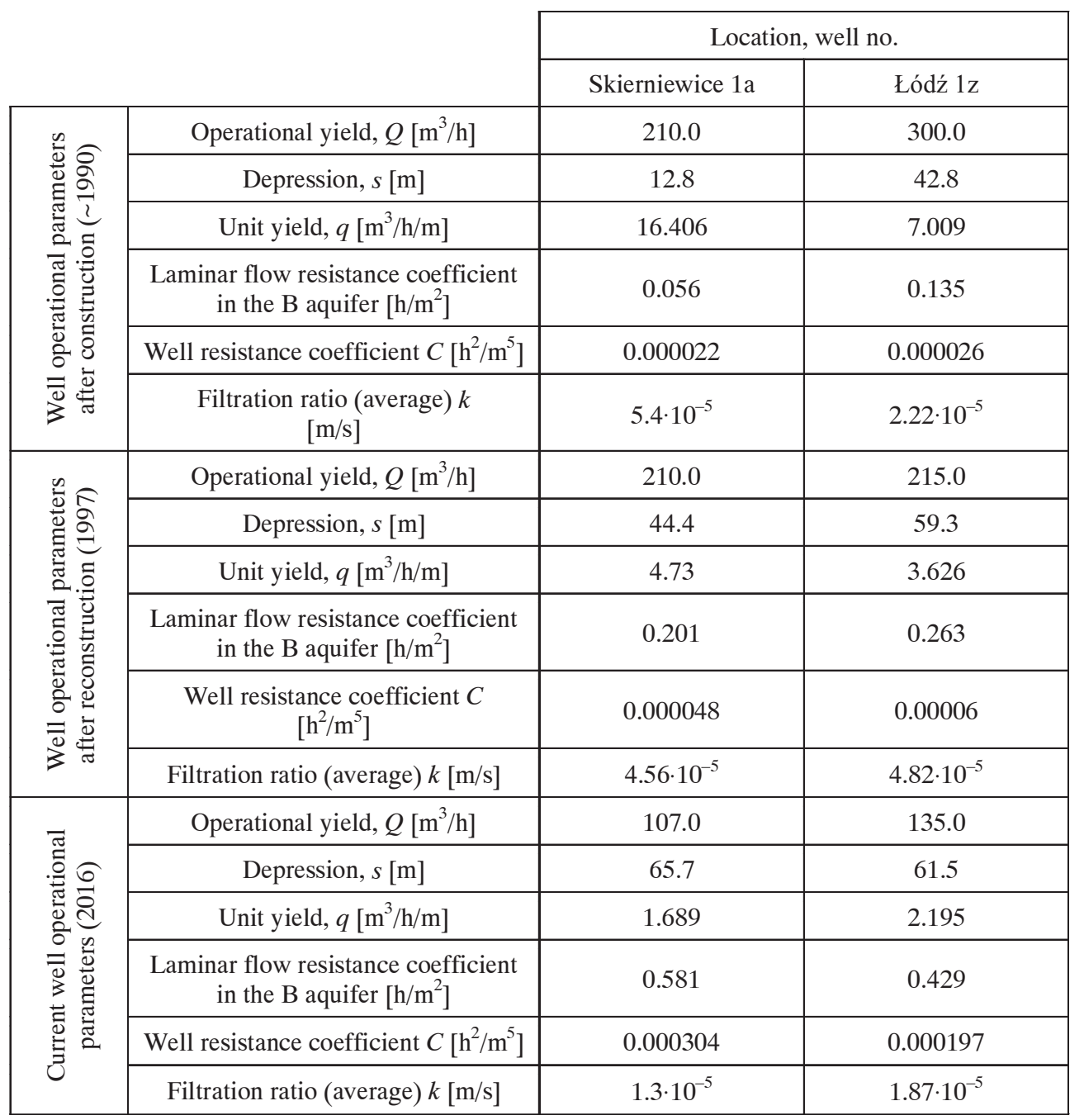


Following the reconstruction, the operation of the 1a well was kept at a constant level, with the yield similar to the approved resources; however, the observed reduction of dynamic water table forced a gradual yield reduction by means of pump choking. After over 16 years of operation the dynamic water table has been lowered by about $16.0 \mathrm{~m}$, and the operational yield has been successively reduced. In 2016, the operational yield was reduced by $50 \%$ in relation to the approved operational resources. A similar water table lowering trend appeared in the $1 \mathrm{z}$ well. Regional requirements of keeping the dynamic water table below $+100.0 \mathrm{~m}$ a.s.l. obligated the user to limit the operational yield by more than $50 \%$ already in the first year of operation. As a result, the declining trend in the wells unit yield was stopped and the wells parameters stabilised. The operating conditions of both wells in successive years are presented in Figures 3 and 4.

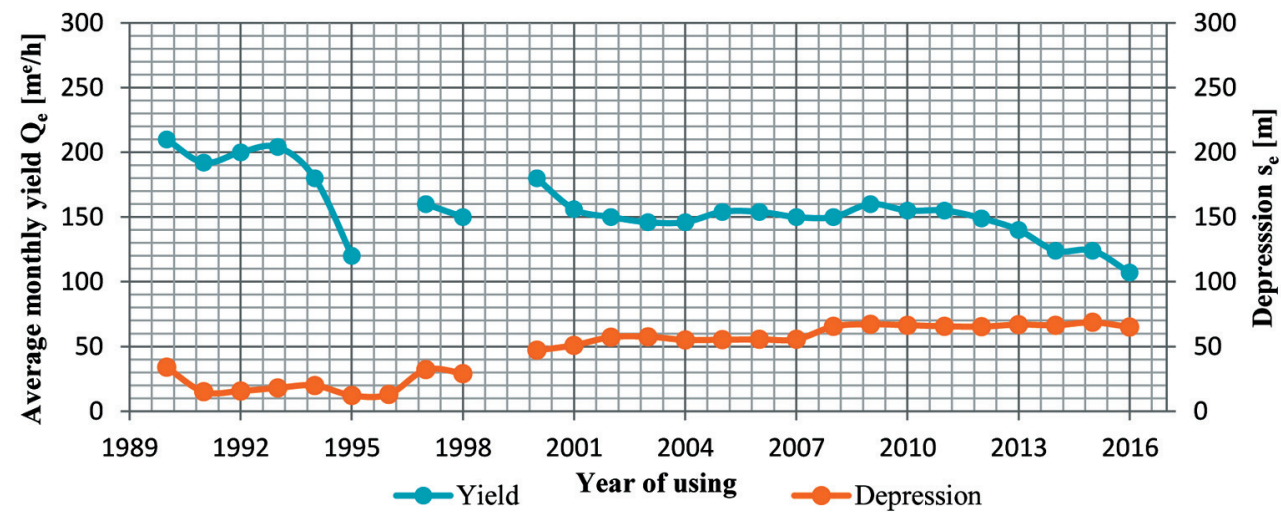

Fig. 3. Variation of average operational yield $Q_{e}\left[\mathrm{~m}^{3} / \mathrm{h}\right]$ and depression $s_{e}[\mathrm{~m}]$ during the operation of the Skierniewice 1a well

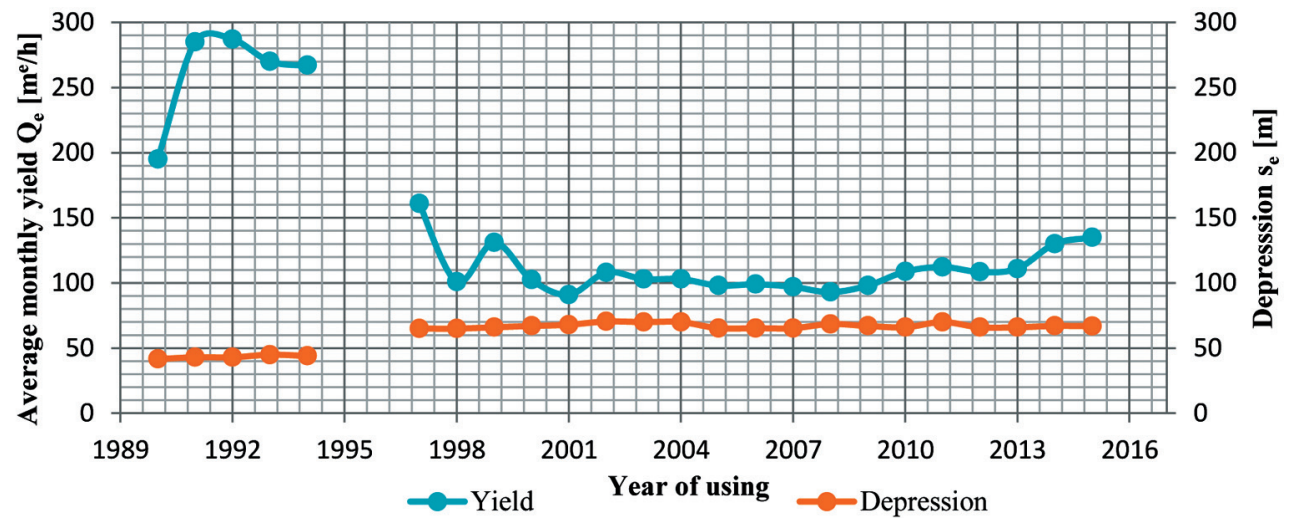

Fig. 4. Variation of average operational yield $Q_{e}\left[\mathrm{~m}^{3} / \mathrm{h}\right]$ and depression $s_{e}[\mathrm{~m}]$ during the operation of the Łódź $1 \mathrm{z}$ well 


\section{CONCLUSIONS}

Due to the change of the length and type of installed screen, the reconstruction of the Lower Cretaceous aquifer water wells entailed a significant reduction of their depths. As a result of using the Johnson continuous slot screens, during the first period after the reconstruction it was possible to keep the operational yield at the level of originally determined resources. However, further operation of the modified wells caused more than a two-fold increase of operational depression.

In order to stop the lowering trend of the dynamic water table during its long-term operation, it was necessary to drastically reduce the well yield. This quickly stabilised the operating parameters of the Lódź $1 \mathrm{z}$ well where the depression was constant in successive years of operation.

After a long and intensive operation of both wells, a clear reduction of filtration parameters in the aquifer near the screens was noticed. The reduced valued of the $k$ filtration ratio indicates deteriorated conditions of water inflow to the well, which may be a result of silting-up of both the side fill and the aquifer in the zone adjacent to the screens. Regardless of the well reconstruction scope, it is necessary to re-determine the operating parameters to ensure further and safe operation of the wells.

\section{REFERENCES}

[1] Bieske E.: Bohrbrunnen. Oldenbourg Verlag, Munchen 1998.

[2] Gonet A., Macuda J., Zawisza L., Duda R., Porwisz J.: Instrukcja obstugi wierceń hydrogeologicznych. Wydawnictwa AGH, Kraków 2011.

[3] Houben G., Treskatis C.: Water Well Rehabilitation and Reconstruction. McGraw-Hill, New York 2007.

[4] Macuda J., Styrkowiec E.: Many years' extraction of groundwater in the context of established usable groundwater reserves. AGH Drilling, Oil, Gas, vol. 34, no. 2, 2017, pp. 419-426.

[5] Manual of water well construction practices. 2nd ed. National Ground Water Association (NGWA), Westerville, OH, 2008.

[6] Operational reports of ZWiK Sp. z o.o. Łódź and ZWiK WOD-KAN Sp. z o.o. Skierniewice.

[7] Archival documentation of the Lower Cretaceous water aquifer intakes - Skierniewice 1a and Łódź 1z.

[8] www.baza.pgi.gov.pl [acsess: 26.03.2018]. 